\title{
Geomorphological hazard analysis along the Egyptian Red Sea coast between Safaga and Quseir
}

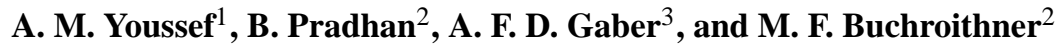 \\ ${ }^{1}$ Department of Geology, Faculty of Science, Sohag University, Sohag, 82524, Egypt \\ ${ }^{2}$ Institute of Cartography, Faculty of Forest, Hydro and Geosciences, Dresden University of Technology, \\ 01062 Dresden, Germany \\ ${ }^{3}$ Department of Geography, Faculty of Art, Sohag University, Sohag, 82524, Egypt
}

Received: 10 January 2009 - Revised: 26 April 2009 - Accepted: 11 May 2009 - Published: 19 May 2009

\begin{abstract}
Geomophological hazard assessment is an important component of natural hazard risk assessment. This paper presents GIS-based geomorphological hazard mapping in the Red Sea area between Safaga and Quseir, Egypt. This includes the integration of published geological, geomorphological, and other data into GIS, and generation of new map products, combining governmental concerns and legal restrictions. Detailed geomorphological hazard maps for flooding zones and earth movement potential, especially along the roads and railways, have been prepared. Further the paper illustrates the application of vulnerability maps dealing with the effect of hazard on urban areas, tourist villages, industrial facilities, quarries, and road networks. These maps can help to initiate appropriate measures to mitigate the probable hazards in the area.
\end{abstract}

\section{Introduction}

Geomorphological hazards are well known worldwide. Lazzari et al. (2006) indicated that the integrated analysis between territorial data (geology, geomorphology and climate) and historical documents showed that the geomorphological hazard has been accentuated by the intense human activity. His work also produced evidence that the human interventions occurring during the historical period have been a determining factor in increasing the hazard level and accelerating the preexisting morphological processes. There are different elements dealing with geomorphological phenomena

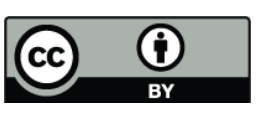

Correspondence to: B. Pradhan (biswajeet.pradhan@mailbox.tudresden.de) including hazard, vulnerability, and risk. Crichton (1999) defined the risk as the probability of a loss, and this depends on three elements "hazard, vulnerability and exposure". If any of these three elements increases or decreases, then risk in that area increases or decreases, respectively. Hazard refers to a characteristic of or phenomenon from the natural environment which has the potential for causing damage to society. Alcantara-Ayala (2002) defined the term hazard as it is often associated with different agents or processes. Some of these parameters include atmospheric, hydrologic, geologic, biologic and technologic. However, Alcantara-Ayala specified the term natural hazards to be considered within a geological and hydro-meteorological framework, where earthquakes, volcanoes, floods, landslides, storms, droughts and tsunamis are the main types. As such natural hazards are threatening events, capable of producing damage to the physical and social space in which they take place not only at the moment of their occurrence, but in the long-term, due to their associated consequences. Natural disasters occur all over the world; however, their impact in developing countries is greater due to the geographical location in zones highly susceptible to natural hazards (natural vulnerability), and also due to the different types of economic, social, political and cultural vulnerabilities that exist (Alcantara-Ayala, 2002).

Examples of natural hazards are flash floods and mass wasting to name a few from others. According to Varnes (1984) scientifically, there are three steps in hazard analysis: susceptibility, possibility (often termed as hazard) and risk.

$$
\begin{aligned}
& \text { - Susceptibility=f (hazard, hazard related factors) (1) } \\
& \text { - Possibility/Hazard=f (Susceptibility, Impact factors) (2) } \\
& \text { - Risk=f (Possibility/Hazard, Damageable objects) (3) }
\end{aligned}
$$

Published by Copernicus Publications on behalf of the European Geosciences Union. 
However, vulnerability refers to a characteristic of society which indicates the potential for damage to occur as a result of hazards (Capobianco et al., 1999). Bell and Glade (2004) proposed a scientific approach to calculate the risks (modified after Varnes, 1984 and Fell, 2000). In the new approach the Risk ( $\mathrm{R})$ is a function of the probability of a hazardous event $(\mathrm{H})$ and its consequences $(\mathrm{C})$ according to the following equation.

\section{Risk $(\mathrm{R})=$ Natural hazard $(\mathrm{H}) \times$ Consequence $(\mathrm{C})$ \\ $\times$ Elements at Risk $(\mathrm{E})$}

They defined the natural hazard as the probability of occurrence of a potentially damaging phenomenon within a specified period of time, within a given area and a given magnitude, on the other hand, consequence meaning the (potential) outcomes arising from the occurrence of a natural phenomenon (including the vulnerability, the probability of temporal and spatial impact as well as the probability of seasonal occurrence), and finally the elements at risk referring to people, houses, etc.

Flooding is one of the most costly disasters in terms of both property damage and human casualties (Alexander, 1993). In the world, all over casualties in terms of death and property damage, flood hazards rank at the top of the list. Floods are the common name for extreme runoff volumes after an intensive storm rainfall event over a drainage basin. Most of the floods have a special impact on people as the fear from the consequences exceeds the actual impacts (Green and Penning-Rowell, 1989). Flooding has a serious impact on economy, agriculture, and others (Alexander, 1993). In addition to natural factors, human activities may also contribute to the occurrence of floods and to flood hazards. The closer the active land use to the main channel stream, the more prone is the land to inundation and consequently, drainage cross-sections that have not been prone to flood hazard become under the threats to flood. In general flood hazards are most prevail in humid regions, but they are equally prevail in arid and semiarid regions in the forms of flash floods, which occur suddenly and wash away anything that comes in its front.

Flash floods are generated when precipitation saturates the drainage capacity of the basin slopes and causes impoundment of the drainage network, resulting in exceptionally high discharge at the basin outlets. Flash flood is increasingly becoming a major contributor to personal and property damage worldwide. It frequently strikes without previous warning. In the study area the problem is aggravated as a result of the uncontrolled economic activities, which led to the development of extensive infrastructures, facilities, and new urban areas near the mouths of the wadis. These facts and the consequent change of the land use increase the risk of future inundations. The most influential factors include the climatic disturbances where extreme and sudden rainfall contributes extensively to this problem. Flash floods are events that occur in many parts of the world including arid regions and they may cause potential hazards to human life and property. These flash floods may rise rapidly due to impervious hard rock catchments and move along the sand and gravel filed wadis which are normally very dry. The flood speeds are usually faster than a person can escape from the rough channels (Khiyami et al., 2005). Flash floods normally reach the sea or are lost in the inland deserts. Flash floods are not uncommon in arid regions and present a potential hazard to life, personal property and structures. After a short period of intensive rainfall, flash floods are formed rapidly and they flow down over extremely dry or nearly dry water courses at speeds more than $1.5 \mathrm{~m} / \mathrm{s}$ faster than a person can escape from the rough and sandy wadi channels (Dein, 1985). Although flash floods are among the most catastrophic phenomena, the volume of the infiltration from floods is a major source of groundwater replenishment to aquifers hydraulically connected with water courses on the surface. Floods are generated as a combined result of two distinctive causes: (1) Primary Causes: these are due to meteorological and atmospheric conditions related to the climatologic features of the reason. The rainfall occurrences, types, intensities, directions, excessive rainfall, etc. are the necessary ingredients among these causes, and (2) Secondary Causes: These are related to the surface features of the drainage basin in terms of geomorphology, geology, vegetation, etc. Although a number of water balance studies have been conducted for a variety of watersheds throughout the world (Flerchinger and Cooley, 2000; Scanlin, 1994; Yin and Brooks, 1992; Kattelmann and Elder, 1997; Mather, 1979) the rainfall-runoff studies in addition to the water balance of the semi-arid range land still offers some interesting challenges.

There are several factors contributing to the flash flooding problem ranging from topography, geomorphology, drainage, engineering structures, and climate. Most flash floods are caused by storms in which a lot of precipitation falls in a short period of time, of both convective and frontal storms. There are, however, many other factors contribute to major influence on the flash floods, especially in desert areas. Saleh (1989) determined some of these factors including rainfall and its characteristics (intensity and duration), water loss (evaporation and infiltration), drainage basins, drainage networks, drainage orders, drainage characteristics, and environmental and human processes. Hassan (2000) mentioned that frequent flash floods seriously affect the highway and human activities along the coastal plains of the Red Sea. Numerous other studies focused on the flood hazards in different areas in Egypt (e.g. El Shamy, 1992a; El-Etr and Ashmawy, 1993; Ashmawy, 1994; Youssef et al., 2005; and Youssef and Hegab, 2005). Flash floods are a major threat to human life and infrastructures (urban areas, roads, and railways). Unfortunately, there is often a lack of data on key hydrological processes in arid areas (Gheith and Sultan, 2002). This limits the ability to understand the flooding process and use this knowledge to minimize its threat to human health and well-being. Ghoneim et al. (2002) described the flash flood potential in 
the wadi Alam, on the Red Sea coast of Egypt. Their work determined the flood-vulnerable sites along the Idfu-Marsa Alam road according to the morphometric parameters and the hydrograph characteristics. They have used digital elevation model (DEM) extracted from the topographic sheets to determine basin characteristics and morphometric parameters. Due to the ungauged basin they used the morphometric parameters to estimate its hydrological response of the flash flood using simple relationships. They did not use the morphometric parameters to determine the hazard degree. However, the current research deals with the utilization of morphometric parameters that have a main influence on the flash flood hazards. Foody et al. (2004) used a hydrological model driven by information on land cover distribution (derived by satellite remote sensing) and soil properties (derived from field measurement) was used to predict sites at risk from large peak flows associated with flash flooding in a wadi located in the Eastern Desert of Egypt.

On the other hand, the transportation systems such as highways are susceptible to rockfalls wherever they cut across or skirt along mountains and similar topographic features (Bunce et al., 1997; Hungr et al., 1999). In the context of highway rock slopes, potentially unstable slopes present hazards and pose risks to the traffic motorists, transportation infrastructure, local economies and the environment. Highway systems may suffer from rockfalls on a daily basis; but these may not be considered hazardous unless rocks enter the roadway (Chau et al., 2004). Although, people are not generally aware of rockfalls except where a particular event results in significant loss of convenience, property, or life (Budetta, 2004), rockfall remains an irritant to many transportation agencies, which are responsible for providing and maintaining safe and reliable highways and routes in an economical fashion. Catastrophic failure of rock cuts and natural slopes can result in property damage, injury, and even life losses. Roads impeded by even small spills of rock material are inconvenient or even dangerous for motorists. Ensuring the stability of rock cuts, whether new or old, and the natural slopes require an evaluation of the structure of the rock. Franklin and Senior (1997a) reported that only 33\% of the analyzed 415 cases of failure in Northern Ontario, Canada, involved the following mechanisms: toppling (23\%), planar sliding (8\%) and wedge sliding (2\%). Mapping of the discontinuity orientations is a serious requirement, before or after the cut has been exposed (Piteau, 1979a). These failures are however easy to determine, and can range from limiting equilibrium analysis to numerical modelling (Hoek and Bray, 1981; Piteau, 1979b, c). Loose rock mass susceptible to the potential failures must be removed or restrained in some way (Piteau, 1979d). Brawner (1994), Franklin and Senior (1997b) have prescribed designs for remediation and mitigation of such possible failures. Franklin and Maerz (1996) have introduced the use of empirical design and rock mass classification for those remedies. Even though no analytical methods are available for this task, other tools are available for the practitioner. Examples for the use of empirical design and rock mass classification are the Oregon RHR (Rock Fall Hazard Rating) system and the Colorado Rock Fall Simulation Program (CSRP) can be used to assess the risk of falling, rolling and bouncing rocks, and to design slope angles, breaks, and ditch dimensions to mitigate their consequences. For the investigated area, studies on the mass deposits are extremely limited. The present study aims to predict the most hazardous sites along the major roads and to prepare some mitigate measures to reduce and avoid these problems. There are many examples of such empirical systems that include Deere's RQD (rock quality designation) system (Deere et al., 1969), Bieniawski's RMR (rock mass rating) system (Bieniawski, 1984), and Barton's Q system (Barton et al., 1974). In addition there are several schemes for the natural slopes and rock cuts as the Oregon RHR (rock hazard rating) system (Pierson and Van Vickle, 1993) and MORFHRS that can predict the most hazard zones along the roads that developed by (Maerz and Youssef, 2004; Maerz et al., 2005) for Missouri Highways. In this paper, the Oregon RHR (rock hazard rating) system (Pierson and Van Vickle, 1993) has been adopted for evaluating the rock cuts and natural slopes.

The current research deals with the evaluation of the geomorphological hazards (flash floods and mass wasting) to delimitate the most susceptibility areas for flash floods and mass wasting in the Red Sea area between Safaga and Quseir, Egypt.

\section{Study area}

The Red Sea district represents one of the main drainage basin systems in Egypt, in which most of the wadis discharge their water to the Red Sea. The district is subjected to flash floods once or twice annually, especially in the spring and autumn. In recent years the frequency of flash floods had increased and caused significant damages to the infrastructure and other facilities in the area. The Red Sea district houses both residential areas, commercial and industrial zones, as well as tourist villages, quarries, roads, railways etc. All these objects are prone to flash flooding. The area is sporadically subjected to heavy showers followed by flash floods which are commonly characterized by sharp peak discharges of short duration. The catchment areas include the coastal road which runs nearly parallel to the shoreline. Also, the transverse roads and railways from west to east cross the lower reaches of most of the drainage basins. Mass deposits seriously affect the roads and railways in the area. The recent flash flood of 1994 had caused severe damages to economy, urban areas, infrastructural facilities, roads and railways (Fig. 1). The study area is located along the Red Sea coast, between Safaga and Quseir, covering the area between latitude $26^{\circ} 4^{\prime} 46^{\prime \prime}$ to $26^{\circ} 49^{\prime} 33^{\prime \prime} \mathrm{N}$ and longitude $33^{\circ} 23^{\prime} 50^{\prime \prime}$ to $34^{\circ} 17^{\prime} 11^{\prime \prime} \mathrm{E}$ (Fig. 2). About 11 drainage basins represent 
Table 1. Climatic data from 1966 up to 2000 for the study area (Egyptian Meteorological Authority 2000 database).

\begin{tabular}{lrrccc}
\hline Station & $\operatorname{Max} T\left({ }^{\circ} \mathrm{C}\right)$ & $\operatorname{Min} T\left({ }^{\circ} \mathrm{C}\right)$ & $\begin{array}{c}\text { Average } \\
\text { humidity }(\%)\end{array}$ & $\begin{array}{c}\text { Annual Rainfall } \\
\left(\mathrm{mm} / \mathrm{in}^{2}\right)\end{array}$ & $\begin{array}{c}\text { Maximum Rainfall } \\
\text { in one day }\left(\mathrm{mm} / \mathrm{in}^{2}\right)\end{array}$ \\
\hline Quseir & $22.5-33.4$ & $13.8-26.7$ & $46-54$ & 1 & 28 (October 1994) \\
Hurghada & $9.7-25.7$ & $21-36.7$ & $43-55$ & 1 & 20 (October 1994) \\
\hline
\end{tabular}
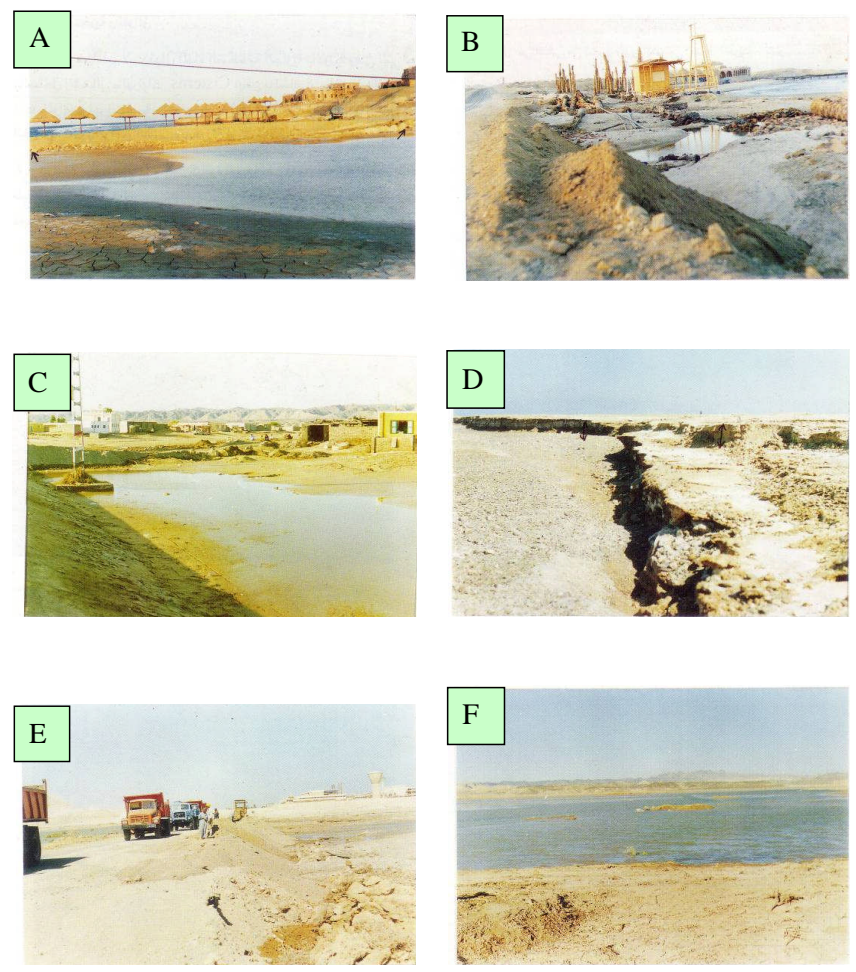

Fig. 1. Damages caused by the 1994 flood in the Red Sea District (A) Cutting of the asphalt roads in the Quseir Area; (B) Damage of the constructions; (C) Damage of the buildings south of Quseir; (D) Erosion features in Wadi Quaiah; (E) Fixing the road after damage by floods; (F) Flood water looks like a lake in Quaiah Area.

the main flooding sites in this area. All these wadis are discharged into the Red Sea. The area is dissected by the vital roads Qena-Safaga and Qeft-Quseir road, as well as Elwadi El-Gadeid-Red Sea Railway. Both roads and the railway are frequently affected by gravitational mass deposits and flash flooding. Recently in the study area, problems related to flash floods have greatly increased, and there is a need for an effective modelling to understand the problem and mitigate its disastrous effects. Human activities such as unplanned rapid settlement development, uncontrolled construction of buildings and major land use changes can influence the spatial and temporal pattern of hazards.

The study area can be categorized into two distinctive zones, each of which has its own geological features: the eastern and the central zone (Fig. 3). The eastern zone is formed by the coastal plains of the Red Sea. The central zone includes the higher relief mountainous part. The geology of the Red Sea coastal plains has already been studied by Hume (1912, 1934) and Akaad and Dardir (1966). The coastal plain strip of the Red Sea between $25^{\circ} 00^{\prime}$ and $26^{\circ} 00^{\prime \prime} \mathrm{N}$ latitude is occupied by Cenozoic rocks of both Tertiary and Quaternary age. The Tertiary rocks are represented by sandstone, lime-grits, conglomerates, carbonateterrigenous sediments, and gypsum. The Quaternary rocks are composed of wadi and terrace deposits consisting of detritus sand, pebbles, and rare boulders. The mountainous central zone consists of the basement rocks, intensively studied by many authors like Hume (1935), El-Ramly (1972), El Gaby et al. (1984), El Shazly (1964), Akaad and El Ramly (1960), and El-Ramly et al. (1970). They concluded that the mountainous areas are essentially composed of panAfrican assemblages comprising gneisses, migmatites, metasediments, ophiolitic melanges, metavolcanics, mafic intrusions, tonalite, granodiorite, younger volcanics, molasse sediments, post-tectonic granites, and trachyte plugs and sheets. These are all dissected by numerous mafic and felsic dykes. Also, the Precambrian units are unconformably overlain by the Phanerozoic sediments especially in the south-eastern (Miocene) parts of the mapped area.

The climate of the area varies considerably from season to season. Generally, it is characterized by hot summers and cooler winters (Table 1). The minimum and maximum temperatures of the Quseir Station are $13.8^{\circ}-26.7^{\circ}$ and $22.5^{\circ}-$ $33.4^{\circ} \mathrm{C}$, respectively and for Hurghada $9.7^{\circ}-25.7^{\circ}$ and $21^{\circ}-$ $36.7^{\circ} \mathrm{C}$, respectively. The annual relative humidity varies between $46 \%-54 \%$ for Quseir and $43-55 \%$ for Hurghada. Rainfalls are very seldom, averaging in about one $\mathrm{mm} / \mathrm{inch}$ per year. The highest recorded rainfall is $28 \mathrm{~mm}$ per year at Quseir and $20 \mathrm{~mm}$ at Hurghada.

\section{Methodology}

GIS provides powerful tools for the assessment of risk and the general management of the natural hazards. Natural hazard maps can be prepared to delineate flood-prone areas. Risk and vulnerability maps help the decision makers for a quick assessment of potential impacts of natural hazards and for the initiation of appropriate measures for 

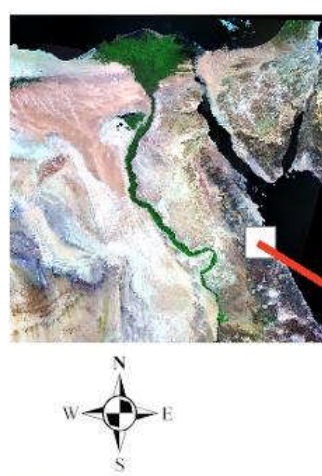

- Urban Areas

PTourist Villages

回 Industrial areas Road

- Qena-Safaga

-Qeft-Quseir

+ Railway

--Coastal Highway Kilometers

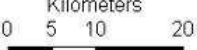

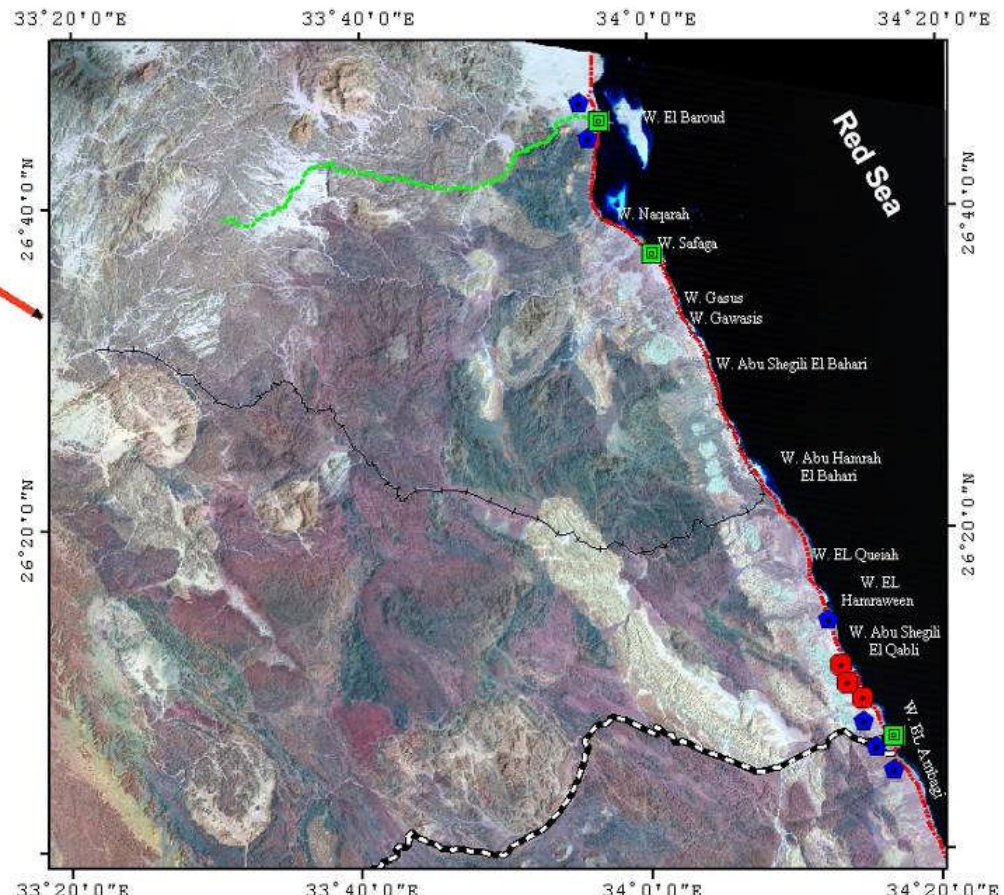

Fig. 2. Study area and hinterland shown by Landsat TM scene.

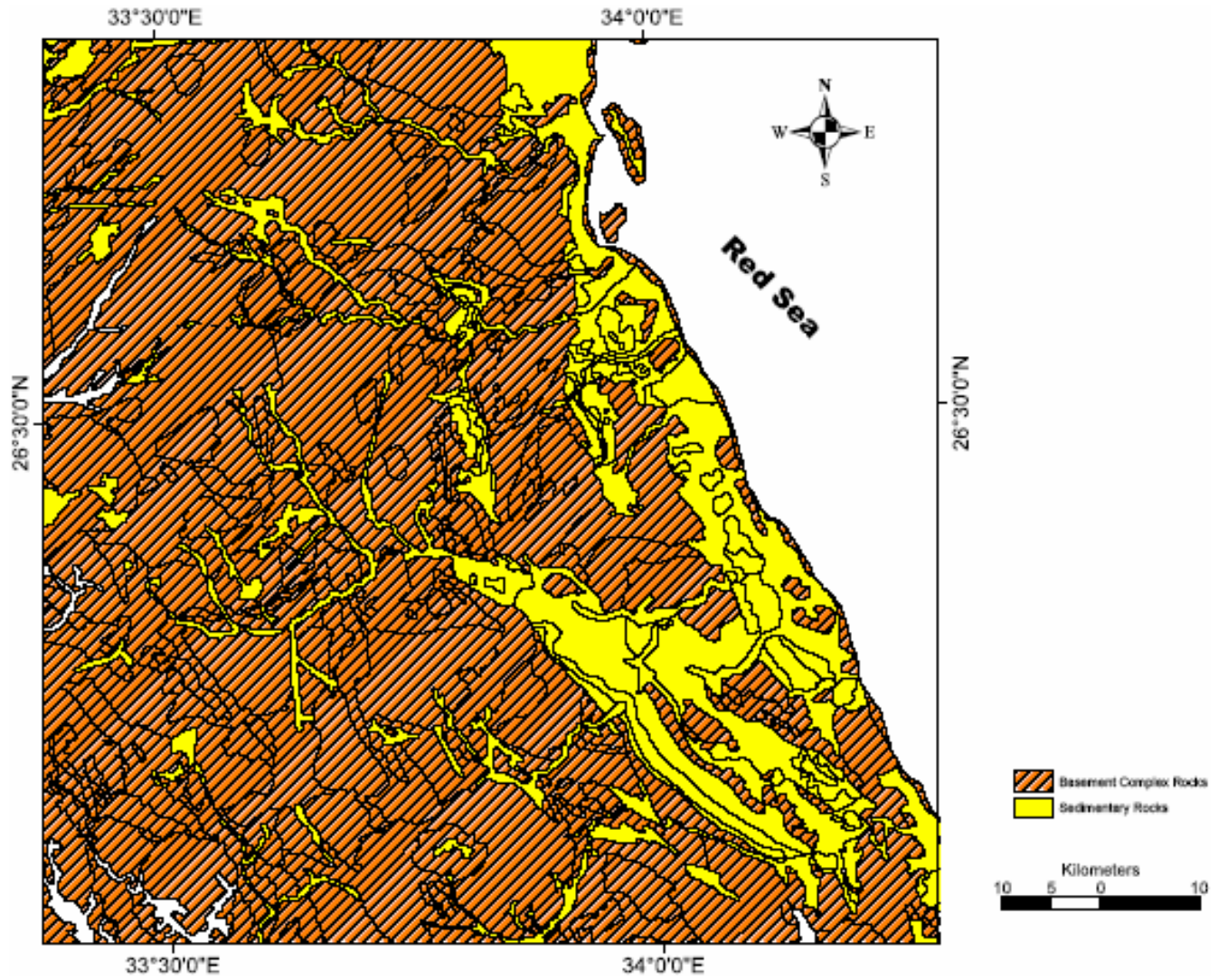

Fig. 3. Simplified geological map for the study area (after Conco, 1987). 


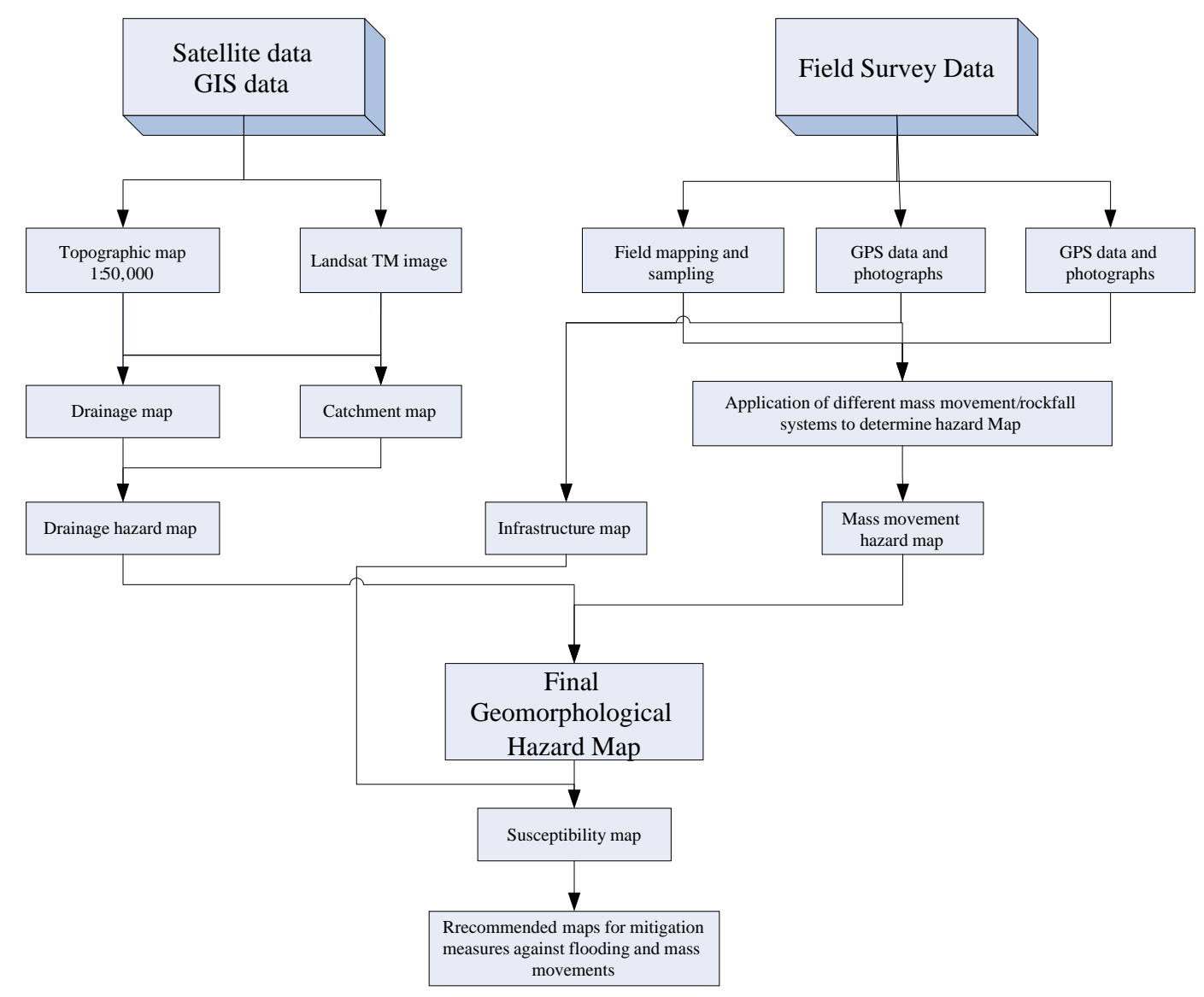

Fig. 4. Flow chart of the geomorphological hazard assessment.

impact reduction. Aforementioned data assist the planners and decision-makers to take correct and in timely steps during pre-disaster periods. They also help them during postdisaster activities for the assessment of damages and losses occur due to flooding. Moreover, GIS provide tools for determining areas affected by floods or forecasting areas likely to be flooded based on the analysis of the drainage basins. Maps of hazard assessment and vulnerability measures are easy to be prepared for sites threatened by flooding and mass wasting. Thus, precautionary measures can be recommended to be taken in order to minimize the flood and mass deposition effects.

For the drainage basin analysis, the methodology adopted in the present study is shown in the form of flow chart with the detailed step wise analysis and is shown in Fig. 4. In the current analysis, topographic maps of scale 1:50000 are used with the aid of Thematic Mapper Landsat mosaic with ground resolution $30 \mathrm{~m}$. These topographic sheets were scanned and then rectified by using IMAGINE ERDAS 8.5 using ground control points with the help of Global Positioning System (GPS). To easily incorporate the data into the geographic information system (ArcGIS 9), all maps have been georeferenced using UTM Coordinate system zone 36 , followed by vectorization (on screen digitizing). Tracing the drainage line from the topographic maps and verified using TM image has been done to produce maps of the basin boundaries (Fig. 5) and the drainage network (Fig. 6). A segment map of the drainage basin patterns and a polygon map of the basin boundaries have been prepared. A separate label point map was vectorized (on-screen digitizing) and unique ID number was assigned to each point for the most important facilities, areas, and quarries along the study area.

For the mass deposition analysis an empirical method has been adopted for the rock mass deposition and characterization. Empirical design is a design methodology that does not use formal design methods, calculations, analytical equations or modelling of any (Brawner, 1994). Instead, it relies on experience and judgment of the geologist or the engineer or geomorphologist. In this study, the Oregon RHR (rock hazard rating) system (Pierson and Van Vickle, 1993) has been used for mass deposition analysis (Table 2). The parameters (Slope height, Ditch effectiveness, Average vehicle risk, Sight distance, Roadway width, Structural condition discontinuous rock, Rock friction, Block size/volume of rock fall event, Climate and presence of water on slope, and Rock fall history) listed in Table 2 have been used in the analysis 

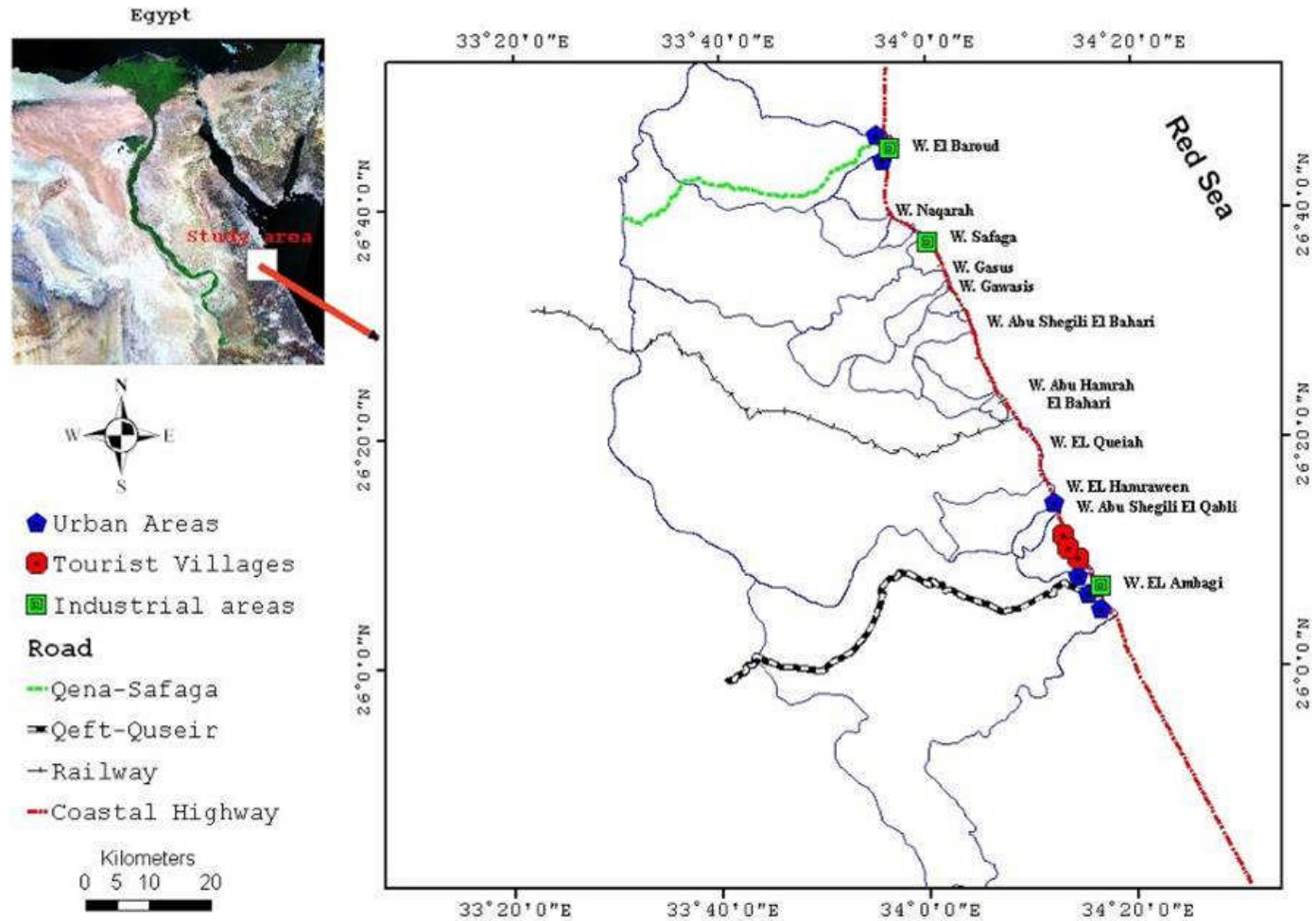

Fig. 5. Outlines of the catchments in the study area.
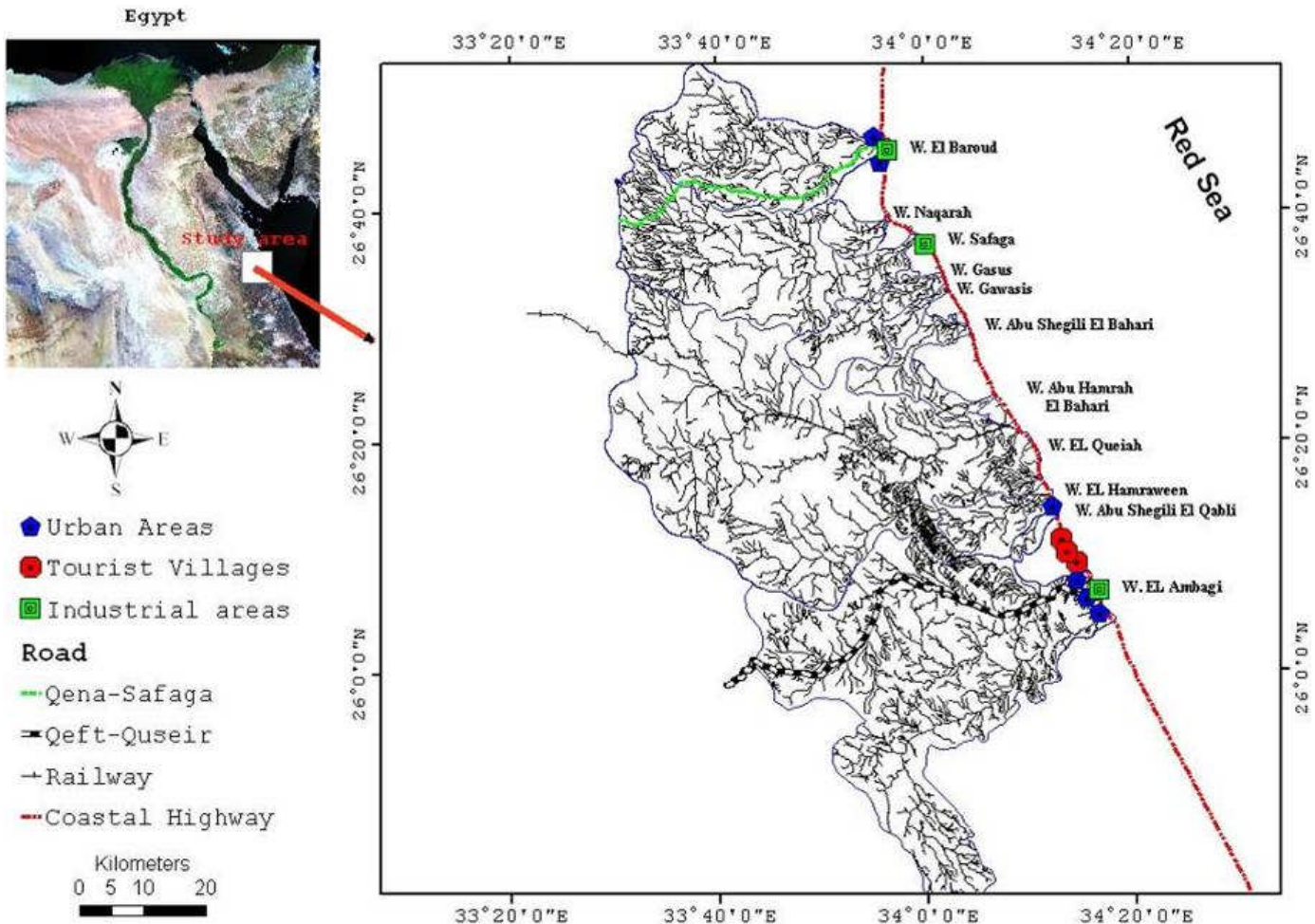

Fig. 6. Drainage network distribution of different basins in the study area. 
Table 2. Rock Hazard Rating System (after Pierson and Van Vickle, 1993).

\begin{tabular}{|c|c|c|c|c|c|}
\hline \multirow{2}{*}{\multicolumn{2}{|c|}{ Category }} & \multicolumn{4}{|c|}{ Rating criteria and score } \\
\hline & & Points 3 & Points 9 & Point 27 & Point 81 \\
\hline \multicolumn{2}{|c|}{ Slope height } & $25 \mathrm{ft}$ & $30 \mathrm{ft}$ & $75 \mathrm{ft}$ & $100 \mathrm{ft}$ \\
\hline \multicolumn{2}{|c|}{ Ditch effectiveness } & $\begin{array}{l}\text { Good } \\
\text { catchment }\end{array}$ & $\begin{array}{l}\text { Moderate } \\
\text { catchment }\end{array}$ & $\begin{array}{l}\text { Limited } \\
\text { catchment }\end{array}$ & No catchment \\
\hline \multicolumn{2}{|c|}{ Average vehicle risk } & $\begin{array}{l}25 \% \text { of } \\
\text { the time }\end{array}$ & $\begin{array}{l}50 \% \text { of } \\
\text { the time }\end{array}$ & $\begin{array}{l}75 \% \text { of } \\
\text { the time }\end{array}$ & $\begin{array}{l}100 \% \text { of } \\
\text { the time }\end{array}$ \\
\hline \multicolumn{2}{|c|}{$\begin{array}{l}\text { Present of decision } \\
\text { sight distance }\end{array}$} & $\begin{array}{l}\text { Adequate site distance, } \\
100 \% \text { of low } \\
\text { design value }\end{array}$ & $\begin{array}{l}\text { Moderate sight distance, } \\
80 \% \text { of low } \\
\text { design value }\end{array}$ & $\begin{array}{l}\text { Limited site distance, } \\
60 \% \text { of low } \\
\text { design value }\end{array}$ & $\begin{array}{l}\text { Very limited sight } \\
\text { distance, } 40 \% \text { of } \\
\text { low design value }\end{array}$ \\
\hline \multicolumn{2}{|c|}{$\begin{array}{l}\text { Roadway width including } \\
\text { paved shoulders }\end{array}$} & $44 \mathrm{ft}$ & $36 \mathrm{ft}$ & $28 \mathrm{ft}$ & $20 \mathrm{ft}$ \\
\hline \multirow{4}{*}{ 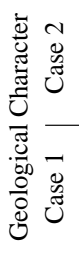 } & Structural condition & $\begin{array}{l}\text { Discontinuous Joints, } \\
\text { favorable orientation }\end{array}$ & $\begin{array}{l}\text { Discontinuous joints, } \\
\text { random orientation }\end{array}$ & $\begin{array}{l}\text { Discontinuous joints, } \\
\text { adverse orientation }\end{array}$ & $\begin{array}{l}\text { Continuous joints, } \\
\text { adverse orientation }\end{array}$ \\
\hline & Rock friction & Rough, irregular & Undulating & Planar & Clay infilling or slickensided \\
\hline & Structural condition & $\begin{array}{l}\text { Few differential } \\
\text { erosion features }\end{array}$ & $\begin{array}{l}\text { Occasional erosion } \\
\text { features }\end{array}$ & $\begin{array}{l}\text { Many erosion } \\
\text { features }\end{array}$ & $\begin{array}{l}\text { Major erosion } \\
\text { features }\end{array}$ \\
\hline & Difference in erosion & Small difference & Moderate difference & Large difference & Extreme difference \\
\hline \multicolumn{2}{|c|}{$\begin{array}{l}\text { Block size or Quality } \\
\text { of rockfall event }\end{array}$} & $1 \mathrm{ft} 3$ cubic Yards & $2 \mathrm{ft} 6$ cubic Yards & $3 \mathrm{ft} 9$ cubic Yards & $4 \mathrm{ft} 12$ cubicyards \\
\hline \multicolumn{2}{|c|}{$\begin{array}{l}\text { Climate and presence } \\
\text { of water on slope }\end{array}$} & $\begin{array}{l}\text { Low to moderate precipitation; } \\
\text { no freezing periods, } \\
\text { no water on slope }\end{array}$ & $\begin{array}{l}\text { Moderate precipitation or } \\
\text { short freezing periods or } \\
\text { intermittent water on slope }\end{array}$ & $\begin{array}{l}\text { High precipitation or } \\
\text { long freezing periods or } \\
\text { continual water on slope }\end{array}$ & $\begin{array}{l}\text { High precipitation and long } \\
\text { freezing periods or continual water } \\
\text { on slope and long freezing periods }\end{array}$ \\
\hline \multicolumn{2}{|c|}{ Rockfall history } & Few falls & Occasional falls & Many falls & Constant falls \\
\hline
\end{tabular}

since the type of rock cuts and slopes are crystalline in nature. Field investigations using the GPS unit helped us to get the location of the areas affected by mass wasting. This also includes the study of different factors that will affect the stability of the slopes.

\section{Results and discussion}

\subsection{Morphometric analysis of drainage basins}

The drainage systems, of different wadis threaten the Red Sea coast areas between Safaga and Quseir, as well as the roads and railways connecting and crossing the area, are external, well developed, and highly integrated. They are significantly controlled by geological structure and lithology. These basins originate mainly in mountainous highland of basement rocks which are flanked in east by a relatively low dipping sedimentary strip. The area consists of 11 drainage basins, 4 main basins namely; Ambagi, El Baroud, El Queih, and Safaga, with 7 other small basins, namely Naqarah, Abu Sheqili El Bahari, Abu Sheiqili El Qibli, Gasous, Gawasis, El Hamraween, and Abu Hamra El Bahari. Most of these wadis flow in west-east direction to the Red Sea coast with its villages, urban areas, and industrial sites. The mor- phometric analyses of the catchments areas have been performed. The drainage pattern parameters are listed in Table 3. All the elements have been measured and extracted using ArcGIS 9. The following characteristics have been used to describe each basin: linear drainage basin characteristics and two aerial drainage basin characteristics. These parameters helped to predict the relative flood hazard degree and the capability of the basins for ground water recharge. The linear drainage basin characteristics include stream ordering (Strahler, 1952), the mean of the bifurcation ratio, the total drainage length (Carlston and Langhein, 1960), the drainage frequency (Horton, 1945), and the drainage density (Melton, 1957). The aerial drainage basin characteristics include drainage basin area, length, width, and perimeter, as well as the length of the overall flow-lines (Horton, 1945). The morphometric data are then sorted and used for the GISbased hazard assessment analysis.

In order to evaluate the hazard probability of the different basins, some of the morphometric parameters were used. These morphometric parameters include drainage density, drainage frequency and bifurcation ratio. Drainage density is a measure of the total network lengths of the basin to the total area of this basin (Melton, 1957). Drainage frequency is the ratio of total number of all stream segments in the basin to the total area of the basin (Horton, 1945). They concluded 
Table 3. Morphometric parameters of the drainage basins.

\begin{tabular}{lrrrrrr}
\hline Name & $\mathrm{A}\left(\mathrm{Km}^{2}\right)$ & $\mathrm{L}(\mathrm{Km})$ & $\mathrm{W}(\mathrm{Km})$ & $\mathrm{P}(\mathrm{Km})$ & $\mathrm{TL}(\mathrm{Km})$ & $\mathrm{TDN}$ \\
\hline W. AbuHamraEl Bahari & 44.83 & 17.6 & 4.76 & 38.87 & 42.987 & 24 \\
W. Abu Sheqili El Bahari & 100.73 & 22.07 & 11.97 & 65.06 & 94.147 & 45 \\
W. Abu Sheqili El Qibli & 26.19 & 11 & 3.6 & 27.2 & 20.961 & 8 \\
W. Ambagi & 1546.1 & 58.97 & 35.55 & 247.44 & 1639.4 & 1502 \\
W. El Baroud & 516.29 & 41.68 & 24.43 & 108.74 & 548.08 & 456 \\
W. El Hammraween & 130.53 & 19.09 & 10.29 & 61.16 & 143.26 & 120 \\
W. El queih & 1928.43 & 74.02 & 41.39 & 242.66 & 1636.5 & 1468 \\
W. Gasus & 185.59 & 27.84 & 12.65 & 81.07 & 171.03 & 168 \\
W. Gawasis & 36.76 & 13.25 & 5.34 & 32.89 & 36.694 & 23 \\
W. Naqara & 69.58 & 14.75 & 6.45 & 37.98 & 67.986 & 56 \\
W. Safaga & 710.17 & 55.28 & 19.18 & 156.19 & 762.42 & 576 \\
& & & & & &
\end{tabular}

$\mathrm{W} .=$ Wadi, $\mathrm{A}=$ area, $\mathrm{L}=$ length, $\mathrm{W}=$ width, $\mathrm{P}=$ perimeter, $\mathrm{TL}=$ total length, $\mathrm{TDN}=$ total drainage number

that many streams per unit area mean that more water is moving off of the surface, rather than soaking into the soil. They also mentioned that drainage density and frequency depend upon both climate and physical characteristics of the drainage basin. Soil permeability and underlying rock type affect the runoff in a watershed; impermeable ground or exposed bedrock will lead to an increase in surface water runoff and therefore to more frequent streams. Rugged regions or those with high relief will also have a higher drainage density and frequency than other drainage basins if the other characteristics of the basin are the same. However, the bifurcation ratio is the average ratio of number of streams of a given order to number in next higher order, dimensionless. McCullah (1986) indicates that the bifurcation ratio is a very important factor that control the runoff where the amount of runoff increased by decreasing the bifurcation ratio. Two different approaches, bifurcation ratio versus drainage density and bifurcation ratio versus drainage frequency, were applied to determine the hazard degree for each basin (ElShamy, 1992b). El-Shamy (1992b) has established empirical diagrams according to his work in the Egyptian drainage basins. He divided his diagrams into three zones, the first zone (A) is characterized by high possibility for flash floods and low possibility for the groundwater aquifer recharging, the second zone (B) is characterized by moderate possibility for flash floods and moderate possibility for recharging the groundwater aquifer, and the third zone $(\mathrm{C})$ is characterized by less possibility for flash floods and high possibility for recharging the groundwater aquifer. Figures $7 \mathrm{a}$ and $\mathrm{b}$ show these approaches with zones A, B, C. The data from both diagrams used to determine the overall hazard degree. If a basin plotted in zone B in the first diagram (Moderate possibility of flash floods) and located in zone $\mathrm{C}$ in the second diagram (High possibility for flash floods) the overall hazard degree for this basin will be high possibility for flash floods which represents the more "conservative" situation.
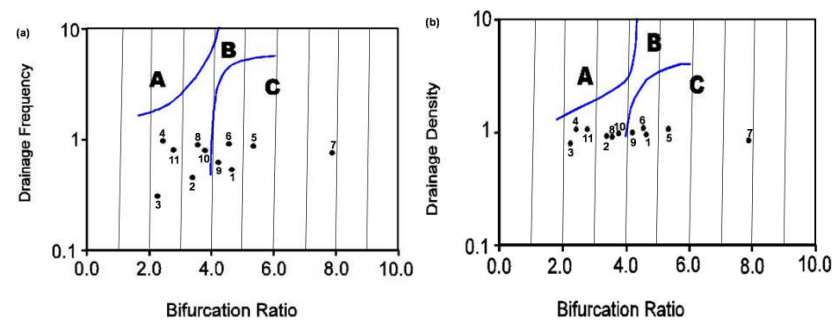

Fig. 7. Hazard degree according to drainage density vs. bifurcation ratio following El-Shamy's and drainage frequency vs. bifurcation ratio following El-Shamy's (1992b) approach. Note $(1=\mathrm{W}$. AbuHamraEl Bahari, $2=\mathrm{W}$. Abu Sheqili El Bahari, 3=W. Abu Sheqili El Qibli, 4=W. Ambagi, 5=W. El Baroud, 6=W. El Hammraween, 7=W. El Queih, 8=W. Gasus, $9=$ W. Gawasis, $10=$ W. Naqara, $11=$ W. Safaga).

The bifurcation ratio, drainage density, and drainage frequency data for the different basins in the study area (Table 3) were plotted in the El-Shamy's diagram (Fig. 7). According to the relation between Bifurcation ratio versus drainage frequency six basins (W. Abu Sheqili El Bahari, W. Abu Sheqili El Qibli, W. Ambagi, W. Gasus, W. Naqara, and W. Safaga) are located in zone B which represents moderate possibility for flash floods and five basins (W. AbuHamraEl Bahari, W. El Baroud, W. El Hammraween, W. El Queih, and W. Gawasis) are located in zone $\mathrm{C}$ which represents low possibility for flash floods (Fig. 7a, Table 4). In addition, according to the relation between Bifurcation ratio versus drainage density six basins (W. Abu Sheqili El Bahari, W. Abu Sheqili El Qibli, W. Ambagi, W. Gasus, W. Naqara, and W. Safaga) are located in zone B which represents moderate possibility for flash floods and five basins (W. AbuHamraEl Bahari, W. El Baroud, W. El Hammraween, W. El Queih, and W. Gawasis) are located in zone C which represents low possibility for flash floods (Fig. 7b, Table 4). 

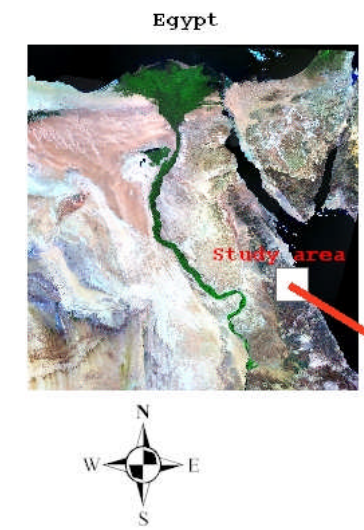

- Urban Areas

- Tourist Villages

回 Industrial areas Road

--. Qena-Safaga

-Qeft-Quseir

+ Railway

--Coastal Highway

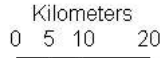

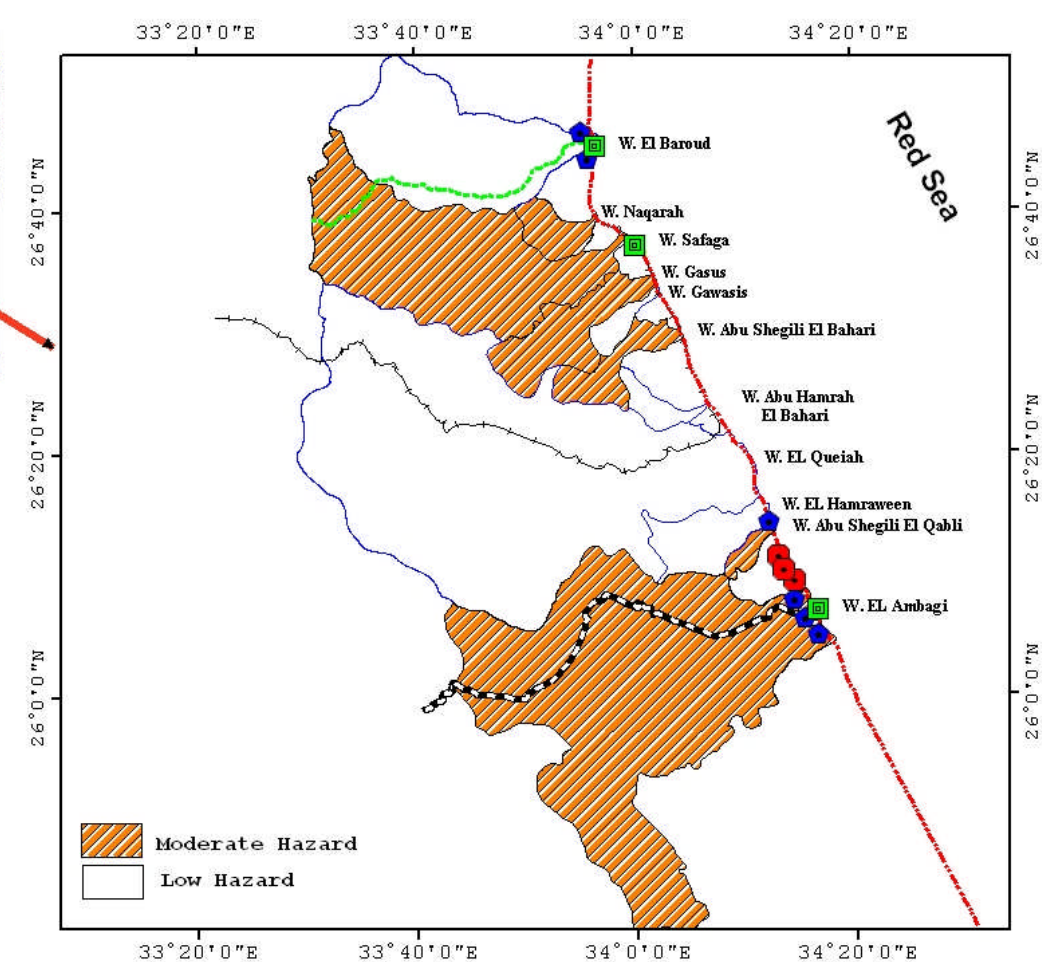

Fig. 8. Drainage basin hazard map.

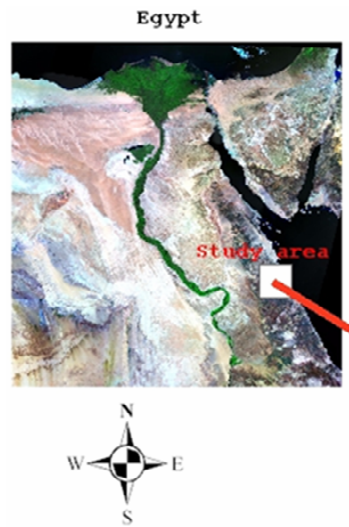

$\Delta$ Urban Areas

$\boxplus$ Tourist Villages

$\checkmark$ Industrial areas

Road

--Qena-Safaga

=Qeft-Quseir

-Railway

--Coastal Highway

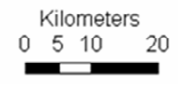

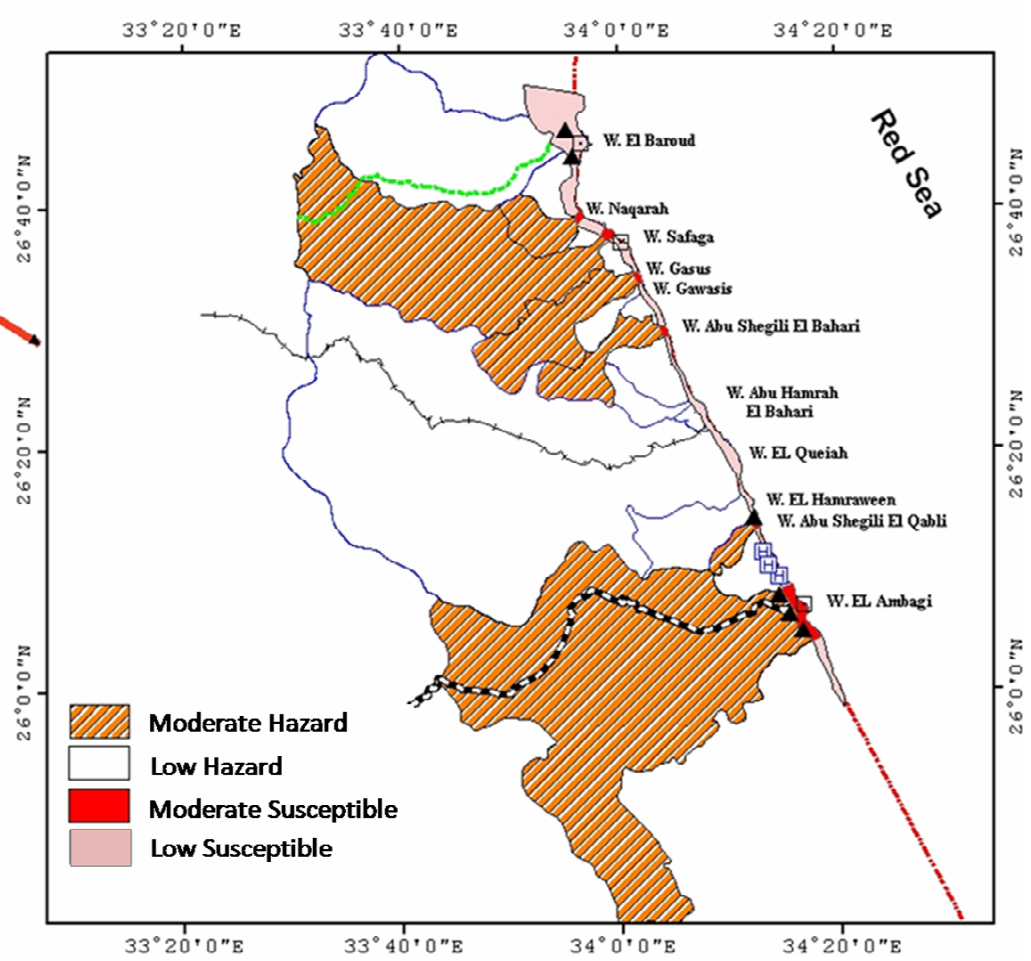

Fig. 9. Areas along the coast prone to floods. 


\subsection{Flash flood hazard map}

Flash-flood-prone wadis (dry channels cut into the terrain) were delineated and assessed using GIS to determine the hazard of flash floods in each basin between Quseir and the Safaga area. For the creation of the hazard map, the data extracted from El-Shamy's model (Table 4) have been applied for each drainage basin in the study area. The overall hazard degree which determined by comparing the hazard degree resulted from bifurcation ratio versus drainage frequency and bifurcation ration versus drainage density (Table 4) indicate that six basins have moderate possibility of flash floods and five basins have low possibility of flash floods. The overall hazard degree was added to the GIS database to assist in constructing the drainage basin hazard map for the most hazardous basins and is shown in Fig. 8. This hazard map was overlaid by the infrastructure facilities (road and railways), urban areas, touristic villages, and industrial areas and is shown in Fig. 8.

\subsection{Susceptibility maps of areas and roads}

In the present study, the most susceptible zones have been performed using a subjective and qualitatively method. So to make the results better understandable separate classes have been introduced as moderate and low susceptible areas. Susceptibility maps for both the areas along the coast and the road and railways have been generated and shown in Figs. 9 and 10. For the costal areas the intersection with the moderate hazard basins with the coastal class indicate a moderate susceptible zones for flash floods and the intersection of the low hazard basins with the costal class indicate a low susceptible areas for flash flood hazards. On the other hand, for the roads and railway, the most susceptible zones that will be more prone to be damaged by flash floods have been determined only along the moderately hazard basins. The intersections between the perpendicular wadis with road and railway are the most areas that susceptible to be damaged due to erosion by flash floods. The final results of this analysis are shown as susceptibility maps (Figs. 9 and 10).

\subsection{Mass deposition hazard assessment}

Multiple field investigations have been carried out to evaluate the rock slope sections in the study area. Field investigations and data interpretations show that there are two types of failures recorded in the study area.

1. Planar, wedge, and toppling failures. In which the discontinuities are oriented in such a way that they contribute to create wedge, planar, or toppling failures.

2. Raveling type failure modes this type of failure is not related to discontinuities and includes raveling, overhang/undercutting, and rolling blocks for both rock cuts and natural slopes.
Table 4. Hazard degree analysis following El-Shamy's (1992b) approach.

\begin{tabular}{lcccccc}
\hline Name & BR & F & HD1 & D & HD2 & FHD \\
\hline W. AbuHamraEl Bahari & 4.64 & 0.54 & L & 0.96 & L & L \\
W. Abu Sheqili El Bahari & 3.39 & 0.45 & M & 0.93 & M & M \\
W. Abu Sheqili El Qibli & 2.25 & 0.31 & M & 0.80 & M & M \\
W. Ambagi & 2.42 & 0.97 & M & 1.06 & M & M \\
W. El Baroud & 5.34 & 0.88 & L & 1.06 & L & L \\
W. El Hammraween & 4.54 & 0.92 & L & 1.10 & L & L \\
W. El Queih & 7.86 & 0.76 & L & 0.85 & L & L \\
W. Gasus & 3.54 & 0.91 & M & 0.92 & M & M \\
W. Gawasis & 4.20 & 0.63 & L & 1.00 & L & L \\
W. Naqara & 3.77 & 0.80 & M & 0.98 & M & M \\
W. Safaga & 2.78 & 0.81 & M & 1.07 & M & M \\
\hline
\end{tabular}

$\mathrm{W} .=$ Wadi $; \mathrm{Br}=$ Bifurcation Ratio, $\mathrm{F}=$ Frequency, $\mathrm{D}=$ Density, HD1 = hazard degree Br vs. F, HD2 = hazard degree BR vs. D, and FHD = Final hazard degree from HD1 and HD2. L: low hazard (low possibility for flash floods); M: moderate hazard (moderate possibility for flash floods); and $\mathrm{H}$ : high hazard (high possibility for flash floods).

In the study area it was so clear that there are both types of failure modes along the natural slopes and rock cuts and is illustrated in Fig. 11. Some terrains are characterized by most notably flat discontinuities with vertical jointing, where planar and wedge slides are unusually not found, the predominant failure mechanism being of the raveling type. These raveling failures, whether slow, time-dependent or fast and catastrophic are much more difficult to analyze. Analytical techniques for prediction are non-effective, and remediation judgments are typically made with on-site engineering judgment of an experienced specialist, who must then balance the risk in terms of probability of failure and consequence of failure, against the cost of effective remediation.

In this study, various outcrop data were collected and classified according to the Oregon RHR (rock hazard rating) system (Pierson and Van Vickle, 1993) in some meaningful way based on parameters that are both easy to measure and are useful as predictors of rock behaviours.

The stability of rock cut and the natural slopes along the roads and railways in the study area is controlled by several geologic factors. The frequency and orientation of discontinuities as well as their properties affecting the quality or strength of the rock mass, which influences the stability of the rock mass have been investigated. The Oregon RHR (rock hazard rating) system (Pierson and Van Vickle, 1993) has been applied on the natural slopes and road cuts along the roads and railways in the study area (75 stations). Both raveling failure and planner wedge, and toppling failures are predominant in the areas and are shown in Fig. 11. The rating value for each parameter has been determined according to Pierson and Van Vickle (1993). The final value for the overall rating is determined by summation all the rating values for all parameters at each station. According to (Pierson 

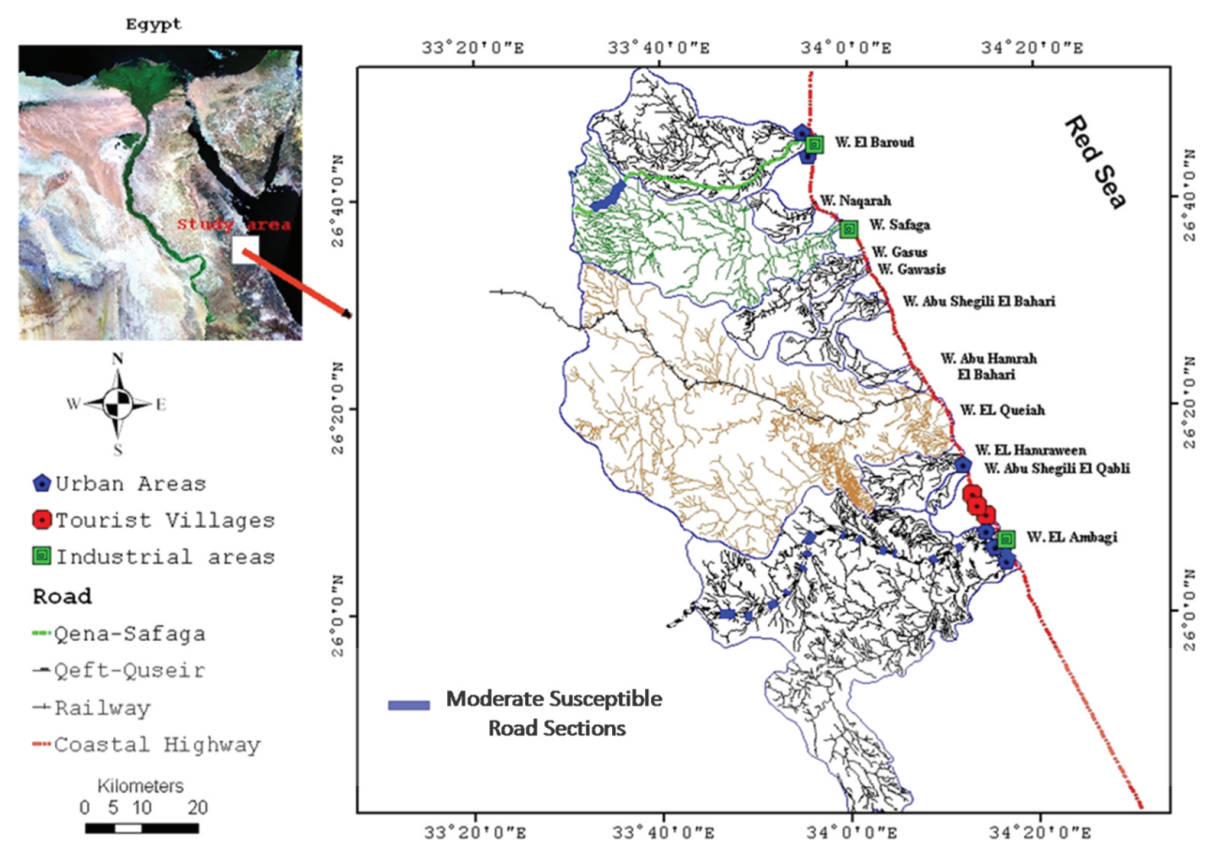

Fig. 10. Portions of roads and railways prone to future flooding.
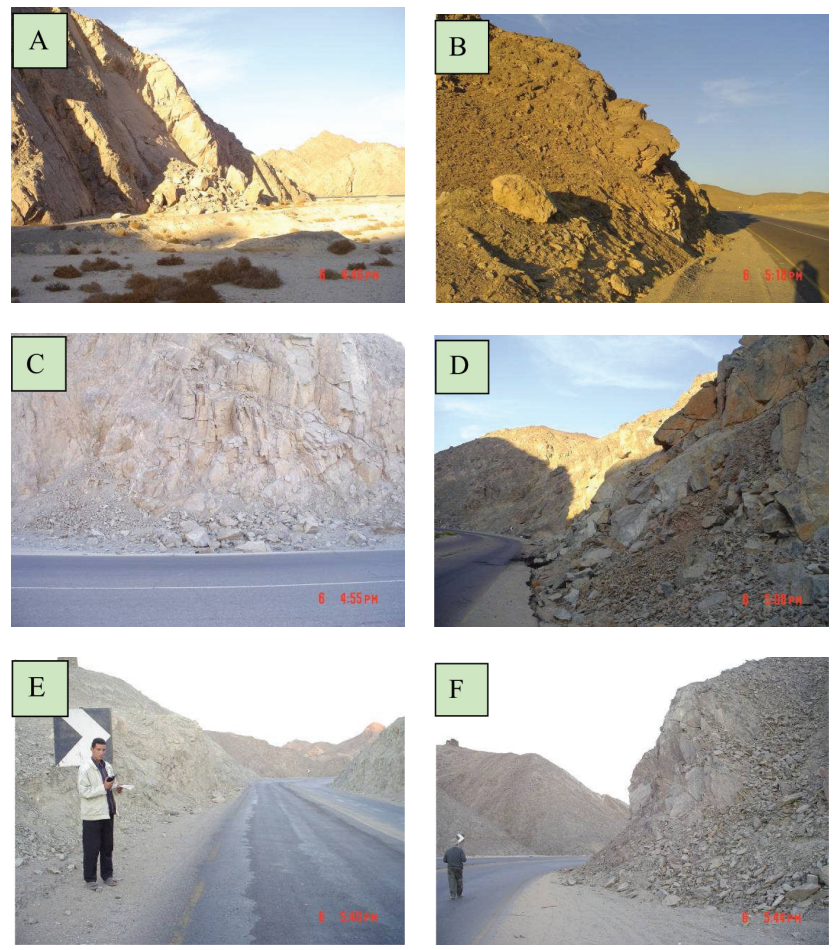

Fig. 11. Different failure types along the roads in the study area. (A) Planar failure; (B) Raveling Failure; (C) Blocks of different sizes on the road after clearing; (D) Blocks ready to slide; (E) and (F) GPS-based road inspection. and Van Vickle, 1993) the final rating can be classified into values greater than 500 require immediate remediation (high risk); rating values between 300 and 500 require corrective measures (moderate risk), whereas rating values of 300 or less consider stable (low risk) and require no remediation action. The analysis of all station along the roads and railway in the study area indicate that 40 stations were determined to be dangerous. The RHRS values for these stations range between 300 and 500. These stations require urgent remedial measures. Once, the data and associated classification was recorded, this information was entered into the GIS database. Also, an attribute table was generated with the information about each site. The attribute table has the data from office and field, as well as the rating of these sites has been applied to determine the risk degree. In this study, the location of the high risk cuts/slopes is shown in the mass wasting hazard map as points (Fig. 12). With spatial referencing, data on rock cut features can be correlated with other data features roadways, topographic maps, aerial photographs, and bedrock geology. A query-building feature was used to call up the highly risk cuts and slopes (Fig. 12). The results are displayed on a map or within the current view of the GIS, providing key pieces of information for rock cut analysis and decision making. This will prioritize the rock cut projects according to risk-reduction and cost-benefit scenarios. 


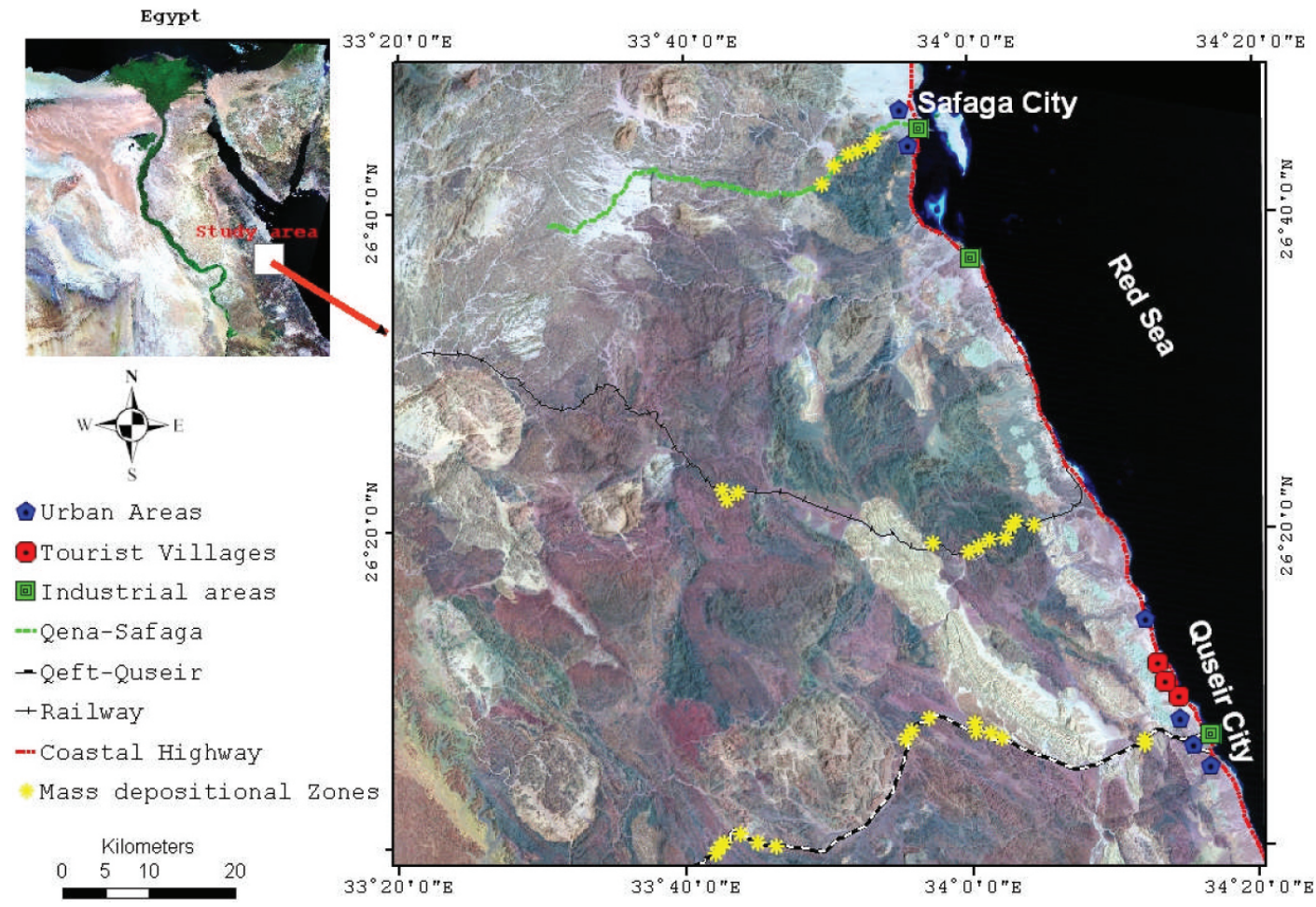

Fig. 12. Mass depositions and rockfall hazard map of the study area.

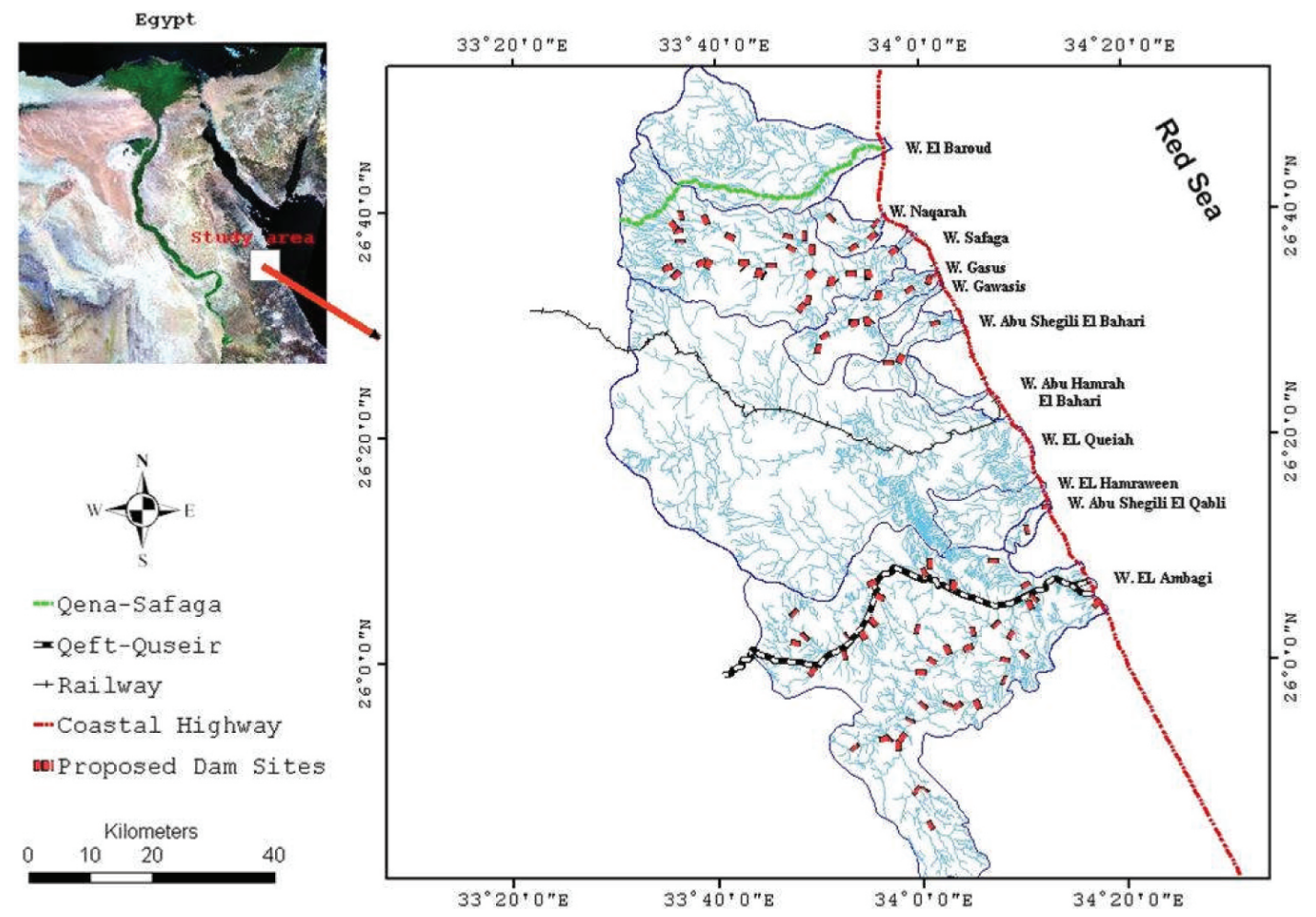

Fig. 13. Dam Sites proposed to minimize the flood hazard degree. 


\section{Conclusions}

Geomorphological hazards like flash floods and mass deposition are destructive and frequently occurring phenomena all over the world. The study area has been affected by flash floods and mass deposition hazards frequently. These hazards strike different types of infrastructures as well as urban areas in the study area causing property damages. These geomorphological hazards acting on the study area will accelerated due to many reasons. One of them is due to the lack of proper warning information about flash floods and mass depositions hazards for the people pass through and live in the prone areas. Another reason is due to severe lack of landuse planning. This might result in even more damages in near future. The evaluation of the geomorphological hazards was carried out on the basis of analyzing the flash flood and mass deposition in the study area, also to analyze an area with different susceptibility to geomorphological hazards. The current research exploits the utilization of remote sensing data, topographic maps and field data for geomorphological hazard analysis in the study areas. Integration between geological, geomorphological, climate, remote sensing, urban, and infrastructure distribution have been used to evaluate the geomorphological hazards. As a conclusion, the hazard and susceptibility maps proved to be very useful tools for determine the hazard areas as well as the most susceptible zones that need mitigation measures and advanced planning. Although flooding and mass deposition are natural phenomena which cannot be completely avoided, however by establishing good mitigation strategies, the disastrous effects can be reduced marginally. Furthermore, a GIS database can help the decision makers to make decisions at time of need.

To mitigate the geomorphological hazard level it is necessary to determine the most susceptible hazard zones and above all, to reduce the mass wasting problems and falsh flood hazards. Generally mitigation measures should be taken for flood and mass deposition protection. It complements other preventive tools like the effective planning of the growth of cities by creating a computerized GIS database for the flood-prone and mass deposition-prone areas. For the flash flood hazards in the study area, set of barriers are proposed at locations in the upstream parts of each basin as well as in the down slopes areas. The high damaging effect of the flash flood is mostly caused by the transportation of big boulders. In that case, the barriers will prevent the boulders to move and the proposed dams will help in saving the runoff water. Figure 13 shows a sketch of the proposed dams to obstruct and slowdown the floodwater current and its load or to spill it through culverts and store it behind the dams. In addition, a warning system has to be established to alarm people before the floods. On the other hand for the mass depositional problems along the roads and railways different suggestions are made as follows:
- To increase the slope shoulder width to avoid the rocks falling from reaching the roads.

- To create a ditch under natural slopes and rock cuts that will take up all fallen material.

- For the critical zones to install a wire mesh that covers (part of) the slopes to decrease the energy of the fallen rocks.

- To put warning signs about the areas most affected by mass deposits and fallen rocks.

Acknowledgements. The authors are thankful to A. Omar (associate professor of geology, Sohag University), in the affiliation for reviewing of the work. Thanks are also due to M. Sabry (professor at geography department, Cairo University) for his helpful remarks. Thanks are due to the anonymous reviewers and handling Editor K. T. Chang for their critical and valuable comments that helped to bring the manuscript to the current form. Special thanks to the authorities of the cities of Safaga and Quseir for kindly providing maps and necessary information about the area.

Edited by: K. Chang

Reviewed by: R. Varathrajoo and another anonymous referee

\section{References}

Akaad, S. and Dardir, A.: Geology of the Red Sea coast between Ras Shagara and Mersa Alam, Egypt, Geol. Surv. Egypt, 35, $67-$ 79, 1966.

Akaad, M. K. and El Ramly, M. F.: Geological history and classification of the basement rocks of the Central eastern desert of Egypt, Geol. Surv. Egypt, 9, 1-24, 1960.

Alcantara-Ayala, I.: Geomorphology, natural hazards, vulnerability and prevention of natural disasters in developing countries, Geomorphology, 47, 107-124, 2002

Alexander, D.: Natural disasters, London; UCL Press, 1993.

Ashmawy, M. H.: Assessment of flash flood potential of the Red Sea drainage basins along the Qena-Safaga highway, Eastern Desert, Egypt ITC Journal, 2, 119-128, 1994

Barton N. R., Lien, R., and Lunde, J.: Engineering classification of rock masses for the design of tunnel support, Rock mechanics 6 , Springer, Berlin Heidelberg New York, 189-236, 1974.

Bell, R. and Glade, T.: Quantitative risk analysis for landslides - Examples from Bíldudalur, NW-Iceland, Nat. Hazards Earth Syst. Sci., 4, 117-131, 2004, http://www.nat-hazards-earth-syst-sci.net/4/117/2004/.

Bieniawski, Z. T.: Rock Mechanics Design in Mining and Tunneling, A. A. Balkema, 1984.

Brawner, C. O.: Rock fall Hazard Mitigation Methods, Participant Workbook, NHI Course No. 13219, US Department of Transportation, Federal Highway Administration, Publication No. FHWA SA-93-085, 1994.

Bunce, C. M., Cruden, D.M., and Morgenstern, N. R.: Assessment of the hazard from rockfall on a highway, Can. Geotech. J., 34, 344-356, 1997.

Budetta, P.: Assessment of rockfall risk along roads, Nat. Hazards Earth Syst. Sci., 4, 71-81, 2004, http://www.nat-hazards-earth-syst-sci.net/4/71/2004/. 
Chau, K. Y., Tang, Y. F., and Wong, R. H. C.: GIS Based Rockfall Hazard Map for Hong Kong, Paper 3B 13 - SINOROCK2004 Symposium, Int. J. Rock Mech. Min., 41(3), CD-ROM, 2004.

Conoco: The Egyptian General Petroleum Corporation, Geological Map of Egypt 1:500 000, 1987.

Crichton, D.: The Risk Triangle, edited by: Ingleton, J., Natural Disaster Management, Tudor Rose, London, 102-103, 1999.

Deere, D. U., Merritt, A. H., and Coon, R. F.: Engineering Classification of In Situ Rock: Air Force Systems Command, Kirtland Air Force Base, Report AFWL-64-144, 1969.

Dein, M. A.: Estimation of floods and recharge volumes in wadies Fatimah, Naaman and Turabah, unpublished M.Sc. thesis, Faculty of Earth Sciences, King Abdulaziz University, Saudi Arabia, 127 pp., 1985.

El-Etr, H. A. and Ashmawy, M. H.: Flash flood vulnerability and mitigation of the Red Sea basins between Latitudes $24^{\circ} 41^{\prime}$ and $25^{\circ} 26^{\prime}$; Proc. Internat. Conf. "30 years Coop.", Geol. Surv. Egypt, Cairo, 335-351, 1993.

El Gaby, S., El Nady, O. M., and Khudeir, A. A.: Tectonic evolution of the basement complex in the CED of Egypt, Geol. Rundsch., 73, 1019-1036, 1984.

El Ramly, M. F.: A new geological map for the basement rocks in the Eastern Desert and Southwestern Desert of Egypt, Ann. Geol. Surv. Egypt, V(II), 1-18, 1972.

El Ramly, M. F., Budanov, V. I., Hussien, A. A., and Dereniuk, N. E.: Ring Complexes in the South Eastern Desert of Egypt, Studies on some mineral deposits of Egypt, Nepheline Syenite Project; Part 3, Geol. Surv. Egypt, Cairo, Egypt, 81-194, 1970.

El-Shamy, I. Z.: Recent recharge and flash flooding opportunities in the Eastern Desert, Ann. Geol. Surv. Egypt, 323-334, 1992a.

El-Shamy, I. Z.: New approach for hydrological assessment of hydrographic basins of recent recharge and flooding possibilities - 10th Symp. Quaternary and Development, Egypt, Mansoura Univ., 18 April, P. 15 (Abstract), 1992b.

El Shazly, E. M.: On the Metallogenetic Map of Egypt, Int. Geol. Congr. Rep., 22, India, New Delhi; Calcutta, 22, 418-425, 1964.

Fell, R.: Landslide Risk Management Concepts and Guidelines Australian Geomechanics Society Sub-Committee On Landslide Risk Management, in: Landslides, International Union of Geological Sciences, Cardiff, UK, 51-93, 2000.

Flerchinger, G. N. and Cooley, K. R.: A ten-year water balance of a mountainous semi-arid watershed, J. Hydrol., 237(1-2), 86-99, 2000.

Foody, G., Ghoneim, E., and Arnell, N.: Predicting locations sensitive to flash flooding in an arid environment, J. Hydrol., 292, 48-58, 2004.

Franklin, J. A. and Senior, S. A.: Outline of RHRON, the Ontario rock fall hazard rating system: Proceedings International Symposium on Engineering Geology and The Environment, Athens, Greece, 647-656, 1997a.

Franklin, J. A. and Senior, S. A.: Rock Fall Hazards - Strategies for detection, assessment, and remediation: Proceedings International Symposium on Engineering Geology and The Environment, Athens, Greece, 657-663, 1997b.

Gheith, H. and Sultan, M.: Construction of a hydrologic model for estimating Wadi runoff and groundwater recharge in the Eastern Desert, Egypt, J. Hydrol., 263, 36-55, 2002.

Ghoneim, E., Arnell, N., and Foody, G.: Characterizing the flash flood hazards potential along the Red Sea coast of Egypt, The
Extremes of the Extremes: Extraordinary Floods, IAHS Publ., 271, 211-216, 2002.

Green, C. H. and Penning-Rowsell, E. C.: Flooding and the quantification of intangibles, J. Inst. Water Env. Man., 3(1), 27-30, 1989.

Kattelmann, R. and Elder, K.: Hydrological characteristics and water balance of an alpine basin in the Sierra Nevada, Water Resour. Res., 27, 1553-1562, 1997.

Hassan, O. A.: Salient Geoenvironmental Parameters of Ras Malaab - Abu Zenima Area, Gulf of Suez, Egypt, with an Emphasis on Flash Flood Potential and Mitigative Measures; Egypt. J. Remote Sensing \& Space Sci., 3, 37-58, 2000.

Hoek, E. and Bray, J. W.: Rock Slope Engineering, 3rd edn, London: Instn. Min. Metall., 1981.

Horton, R.: Erosional Development of Streams and Their Drainage Basins, Hydrophysical Approach to Quantitative Morphology, Geol. Soc. Am. Bull., 56, 275-370, 1945.

Hume, W. F.: Explanatory notes to accompany the Geological map of Egypt, Egypt, Survey Dept. Cairo, 50-60, 1912.

Hume, W. F.: Geology of Egypt, Part I, The fundamental Precambrian rocks of Egypt and Sudan, their distribution age and character, 2, 300-320, 1934.

Hume, W. F.: The Late plutonic and intrusive rocks, Part 2: Geol. Surv. Egypt, 2, 301-688, 1935.

Hungr, O. and Evans, S. G.: Hazzard, Magnitude and frequency of rock falls and rock slides along the main transportation corridors of southwestern British Columbia, Can. Geotech. J., 36, 224 238, 1999.

Khiyami, H. A., Şen, Z., Al-Harthy, S. C., Al-Ammawi, F. A., AlBalkhi, A. B., Al-Zahrani, M. I., and Al-Hawsawy, H. M.: Flood hazard evaluation in wadi Hali and wadi Yibah, Saudi Geological Survey, Technical Report, 138 pp., 2005.

Lazzari, M., Geraldi, E., Lapenna, V., and Loperte, A.: Natural hazards vs. human impact: an integrated methodological approach in geomorphological risk assessment on the Tursi historical site, Southern Italy, Landslides, 3, 275-287, 2006.

Maerz, N. H., Youssef, A., and Fennessey, T. W.: New riskconsequence rock fall hazard rating system for Missouri highways using digital image analysis, Environ. Eng. Geosci., XI(3), 229-249, 2005.

Mather, J. R.: Use of the climatic water budget to estimate streamflow, Water Resources Center, University of Delaware, Technical Research Report, July, Dept. Geography Newark DE, 528 pp., 1979.

Melton, M. A.: An Analysis of The Relations among Elements of Climate, Surface Properties and Geomorphology, Project NR 389-042, Tech. Rept. 11, Columbia Univ., 102 pp., 1957.

McCullah, P.: Modern Concept in geomorphology, Oxford Univ. Press., Oxford, UK, 197 pp., 1986.

Pierson, L. A. and Van Vickle, R.: Rock Fall Hazard Rating System - Participants' Manual: FHWA Report - FHWA-SA-93-057, 102-105, 1993.

Piteau, D. R.: Engineering geology considerations and basic approach to rock slope stability analysis for highways. Part A., Rock Slope Engineering Reference Manual: FHWA Report FHWA-TS-79-208, 78 pp., 1979a.

Piteau, D. R.: Approach and techniques in geological structural analysis. Part C, Rock Slope Engineering Reference Manual: FHWA Report - FHWA-TS-79-208, 1979b. 
Piteau, D. R.: Slope stability analysis methods. Part D, Rock Slope Engineering Reference Manual: FHWA Report - FHWA-TS-79208, 1979c.

Piteau, D. R.: Rock Slope Stabilization, Protection and WarningInstrumentation Measures and Related Construction Considerations. Part E, Rock Slope Engineering Reference Manual: FHWA Report - FHWA-TS-79-208, 1979d.

Saleh, A. S.: Flash floods in deserts, A Geomorphic Study of Desert Wadis, Institute of Arab Research, Special Studies Series, 51, 93-98, 1989.

Scanlin, B. R.: Water and heat flux in desert soils: 1, Field studies, Water Resour. Res., 30, 709-719, 1994.

Strahler, A.: Hypsometric (Area-Altitude) Analysis of Erosional Topography, Geol. Soc. Am. Bull., 63(11), 1117-1142, 1952.

Varnes, D. J.: Landslide hazard zonation: A review of principles and practice, UNESCO, France, 1-63, 1984.
Yin, Z. Y. and Brooks, G. A.: Evaporation in the Oketenokee Swamp watershed: a comparison of temperature and water balance methods, J. Hydrol., 131, 293-312, 1992.

Youssef, A. M., Abdel Moneim, A. A., and Abu El-Maged, S. A.: Flood hazard assessment and its associated problems using geographic information systems, Sohag Governorate, Egypt, The Fourth International Conference on the Geology of Africa, Assiut, Egypt, November 2005, 1, 1-17, 2005.

Youssef, A. M. and Hegab, M. A.: Using geographic information systems and statistics for developing a database management system of the flood hazard for Ras Gharib area, Eastern Desert, Egypt, The Fourth International Conference on the Geology of Africa, Assiut, Egypt, November 2005, 2, 1-15, 2005. 